\title{
ARTICLES
}

\section{MILITARY ASPECTS OF MONGOLIAN GEOPOLITICS}

\begin{abstract}
R.Bold*
Three big events have taken place in Mongolia during the last 4 years which are now determining new directions in the na-tional defense policy.

Firstly, the departure of the 39th Field Army of Russia ended 25 years of military presence of the former Soviet Union in Mon-golia. It meant that the defense alliance which existed between the two countries lasted for 71 years is now over. The Soviets sent the troops to Mongolia on three occasions. Two of these were direct or indirect responses to Chinese actions. Since 1911, the Russian forces were stationed in the country for 40 years. The Soviet deployment in Mongolia was evidence of its security inter-ests vies-a vis China. Nevertheless, the longstanding deployment of foreign forces left a mark on Mongolian political culture as is evidenced in the new Constriction.

Secondly, the fourth Constitution of Mongolia does not deny "the invitation of foreign troops legally" saying: "Stationing of foreign troops in the territory of Mongolia, allowing them to cross the state borders for the purpose of passing through the country's territory shall be prohibited unless an appropriate law is adopted" (Paragraph 3, Article 4, Chapter 1)/1/.

In this respect the new defense strategy should be based on the principle of self-defense.

Thirdly, the long-time, political, economic and military isolation is one of major tactic employed by geopolitics.

The political and economic experiences of Mongolia in the last four years would suggest that "to open the doors to the outside world is one thing, to allow them in is another".

It is too early, to decide the formulation of new military aspects of Mongolian geopolitics. Therefore this paper will deal some theo-retical aspects of geopolitics.
\end{abstract}

* R.Bold is Director of the Institute for Strategic Studies. The views expressed in this paper are his and do not represent those of the institute and the Ministry of Defense with which he is affiliated. 
Certainly we live in a world where the relationship between economic security and national security is seen to be closely aligned, with the result that economic self-interest has a major influence on foreign policy, economic aid and economic sanc-tions, all important instruments of external relations.

Defense policy and strategic activity without an economic content is perceived as devoid of purpose. In other words, geo-politics is shifting to geoeconomics. Economics, in turn, in-fluences defense thinking.

\section{Mongolia's military strategic philosophy}

Its geo-strategic location is, perhaps, the prime determinant of a state's survival. States, unlike people, cannot choose their neighbors. Since their location is fixed, they must find the best ways and means of getting along with their neighbors, particu-larly the stronger ones. Hence, actions and interactions of states, as well as friendships and enmities among them, are determined largely by geostrategic realities. As the Indian philosopher, Kautilya, argued: neighboring states are inevitably "natural enemies', while the powers on the other side of state's neighbors are its "natural allies". This line of reasoning was further elaborated, by Chairman Mao who favored "allying with remote enemies against near enemies".

Geography is one of the most basic and enduring of the influences upon state policy, both as regards limitation and opportunities.

At the same time geography has been described as a conditioning rather than as. A determining factor in a state's policy. National strategic thinking is very much a product of geographi-cal conditioning.

Geography and military strategy are interconnected. It is clear that geographical factors (location, size and character of national territory, character of neighbors, and so forth) must per mate defense thinking.

Yet just as individuals are conditioned by the environment in which they grow up, so are governments conditioned by their environment.

The Mongolian military system is greatly influenced by the former Soviet attitudes to distance and space, to discipline and authority, to time and work.

The state of research into strategic culture or indeed, the re-discovery of this culture is still in its infancy in this country but early results are promising.

Psychologically, Mongolia's strategic culture has its roots in the concept of "great powers". Mongolia is surrounded and influenced by two great powers which have different traditions but which are both characterized by common features such as militarism, conservatism, and an emphasis on mass. 
Self-defensive strategic culture should not be militaristic; instead it should be peacefully preventive, sometime pacifist while remaining self-confident. We should not be conservative, instead we should be flexible and pragmatic, we could not rely on mass, and instead we should rely on mass of friends. Mongolia's strategic culture should be modest but not under-developed.

\section{Mackinder's geopolitics and Mongolia}

According to Sir Halford Mackinder "Who rules East Europe commands the Heartland; who rules the heartland commands the World-Island; who rules the World-Island commands the World".

This is a very simplistic and educational theory.

This heartland includes part of the former Soviet Union, Eastern Europe, Mongolia, and Tibet, in other words the Eurasian land mass, which is demographically greater to and has a larger resource base than any other geographic unit.

Furthermore, a very simple application of this simplistic concept to the Mongolian model could be that "Who controls Inner Asia controls the wide region." The application of this theo-retical postulate on is still open. In fact, as Spykman, as one of founders of geopolitics asserted, "Geography is the most funda-mentally conditioning factor in the foreign policy of states be-cause it is the most permanent".

\section{Buffer system and Mongolia}

Mongolia has served as a strategic buffer in the last three decades between the Soviets, and China. Not surprisingly during much of the Sino-Soviet confrontation, the Mongol-Chinese bor-der was, in fact to all intents and purposes, the Sino-Soviet bor-der.

At that time, it was hard to regard Mongolia as a buffer state, despite the fact that Mongolia has all three crucial elements of the buffer state. It is true that buffer states are among the most unfortunate of all states. These situation conies from its location. A buffer state is a country geographically situated between two or more large powers whose function is to maintain peace between them. In other words, buffer means peacekeeper.

Mongolia's experience taught us that an important element of the effectiveness of the buffer state is the condition of power distribution in the buffer system. One aspect of power distribution is that the buffer state should have sufficient strength to maintain self-reliance, domestic stability and unity. If the 
buffer was so weak that it can no longer function as a buffer it could threaten the neighboring powers' security. It could also be easy swallowed.

Leaning towards or establishing closer relations with one of the powers is a delicate game for the buffer state, but it does have advantages as well as risks as shown by the Mongolian ex-perience. The Mongolian military doctrine states: "to remain unaligned with any military alliances or coalitions, except in the event of an immediate military threat or implied threats which threaten the independence and sovereignty of Mongolia"? Non-alignment means no attachment to either of the big neighbors, no alliance with them, and no leaning to one side to oppose the other.

In other words, to respect legitimate security interests of both sides. The development of non-aligned and good neighborly relations with our neighbors should be Mongolia's long-term strat-egy.

Spykman argued that "a buffer state is an illustration of the strategic significance of a specific area for a particular state. Another illustration is the area beyond the neighbor of equal strength- the obvious location for a potential ally"/2/.

Mongolia's strategic location as a buffer state between Russia and China will continue to be an important aspect of the region. Meanwhile, to expand this buffer system beyond Mongolia, to create a buffer system in Inner Asia could quite possibly be the direction of Mongolia's defense thinking.

In conclusion, the following are practical considerations from the abovementioned theoretical deliberations:

1. Despite the shift to geo-economics and the ability of new technology to change geopolitics is growing, still they have limitation.

Geopolitical factors have remained vital for both the survival of Mongolia's democracy and Mongolian defense thinking. The Mongolian way to join the free community lays both through Northeast Asia in the political and economic sense and through Russia and the PRC in geographical terms. Both Russia and China still play critical roles in Mongolia's affairs, but it is becoming increasingly clear that the ability of both neighbors to alter Mongolia's relations with the outside world is diminishing.

Self-reliance is necessary not only for the sake of self-defense but also for making any outside help more appealing to the donor. This was a lesson learned from Kuwait. Defense strategy should emphasis military confidence-building measures instead of focusing on fighting in order to build reliable bridges with the outside world. It is also a lesson from Chechne. Not collective defense, but 
cooperative security which will be the road to collective security at both regional or sub regional levels is going to determine Mongolia's defense thinking.

2. Mongolia, which has traditionally viewed its own security in terms of the Sino-Russian relationship, is coming to a new stage of security. We now have inherited the task of defining our new role in Sino-Russian relations in the context of the heartland and the rim land Asia, specifically Northeast Asia.

3. The world is changing so fast today that we must expect ambiguity and uncertainty. Only by joining the world community can Mongolia have reliable security. We hope that other free nations can take this small nation away from its isolation.

4. Mongolia has determined that its best strategy is to maintain nonaligned, good neighborly relations with both the new Russia and the new China, while at the same time preserving broad political, economic and security relations with outside powers. As professor R.Scalapino has said: "Clearly the Mongols would benefit from relations with all of the major powers" $/ 3 /$.

\section{ENDNOTES}

1. The Constitution of Mongolia. 1992, February, p.2

2. Nicholas J.Spykman. "Geography and Foreign Policy II”.'The American Political Science Review”. April 1938. Vol XXXII, No 2, p.228

3. Robert B.Scalapino. "Major Power Relations in North East Asia". The Asia Society, 1987, p.46 